Ya.S. Borodkin, E.B. Rusanov, Yu.G. Shermolovich

\title{
ISOMERIC BIS(PYRAZOLYL)SULFONES BASED ON BIS(1,1- DIHYDROPOLYFLUOROALKYL)SULFONES. A NEW TYPE OF LIGANDS FOR METAL-POLYMER COMPLEXES WITH SILVER CATION
}

\author{
Institute of Organic Chemistry of the NAS of Ukraine, Kyiv, Ukraine
}

\begin{abstract}
The work is devoted to the methods of synthesis of bis(polyfluoroalkenyl)sulfones and bis(polyfluoromethoxyalkenyl)sulfones as well as to the study of their reactions with diazomethane, resulting in the formation of $\mathrm{N}$-methylated bis(pyrazolyl)sulfones isomers. Methods for the preparation of bis(polyfluoromethoxyalkenyl)sulfones not described previously in the literature have been developed by the addition of triethylamine and trimethylchlorosilane to a solution of the respective bis(polyfluoroalkyl)sulfones and methanol in diethyl ether in an argon atmosphere. A new method for the preparation of a previously unknown bis(3,3-difluoro-2,2-dimethoxypropyl)sulfone was suggested. The reaction occurs at room temperature in methanol in the presence of lithium hydroxide monohydrate. It was found that different regioisomeric bis(polyfluoroalkylpyrazolyl)sulfones are formed when using different methoxy derivatives of bis(polyfluoroalkenyl)sulfones in reaction with diazomethane, depending on the length of the polyfluoroalkyl moiety. These experimental data suggest that the attack of the double bond of methoxy-derived bis(polyfluoroalkenyl)sulfones by a molecule of diazomethane is influenced not only by the presence of an alkoxyl group, but also by the length of the polyfluoroalkyl substituent. The obtained bis(pyrazolyl)sulfones were investigated for the possibility of their use as ligands in the chemistry of metal complexes. It was shown that 5,5'-sulfonylbis[4(difluoromethyl)-1-methyl-1H-pyrazole] forms a polymeric metal complex with silver nitrate. The results of X-ray structural analysis of the prepared coordination compound are presented. According to these results, the silver atom coordinates with two nitrogen atoms of pyrazole cycles of different molecules in the crystal of the obtained metalcomplex compound, forming a supramolecular structure. In our opinion, an important role in this arrangement is played by the nitrate group that is coordinated with two silver atoms. As a result, we observed a supramolecular structure in the crystal that had a spiral structure with some free space in the middle. The paper also presents the results of spectral and X-ray diffraction analysis of a new regioisomeric compound of bis(3hexafluoropropyl-1-methylpyrazolyl)sulfone.
\end{abstract}

Keywords: bis(1,1-dihydropolyfluoroalkyl)sulfones, bis(pyrazoly)sulfones, dipyrazole ligands, coordination polymers, silver complex, silver nitrate.

DOI: $10.32434 / 0321-4095-2021-138-5-21-29$

\section{Introduction}

The pyrazole nucleus is quite rare in natural compounds, but synthetic pyrazole derivatives are intensively used in medicinal chemistry and agrochemistry [1]. At least 33 pyrazole-containing organic compounds are used to treat bacterial infections, malignant tumors, and neurological diseases [2,3].

Since the mid-1990s, the number of known fluorinated pyrazoles for medical use has been increasing significantly. Data on new therapeutic drugs containing fluorinated pyrazole fragments have recently been reviewed in detail [4].

The main reasons for the interest in this topic are connected with the effect of fluorine atoms on the strength of the $\mathrm{C}-\mathrm{F}$ bond and its polarity. The introduction of fluorine atoms or fluoroalkyl groups into an organic molecule results in a significant

(C) Ya.S. Borodkin, E.B. Rusanov, Yu.G. Shermolovich, 2021

Isomeric bis(pyrazolyl)sulfones based on bis(1,1-dihydropolyfluoroalkyl)sulfones. A new type of ligands for metal-polymer complexes with silver cation 
change in its physicochemical properties (pKa value of functional groups, metabolic stability, lipophilicity, etc.).

That is why the methods for the synthesis of fluorine-containing pyrazoles of both known and new types are being intensively studied.

We recently reported that study of the chemical properties of bis(1,1-dihydropolyfluoroalkylalkenyl) $1(\mathrm{a}-\mathrm{c})$ sulfones made it possible to develop methods for the synthesis of new types of fluorinated bis(pyrazolyl)sulfones $2(\mathrm{a}-\mathrm{c})$ and $3(\mathrm{a}-\mathrm{c})$ [5] (Scheme 1).

It should be mentioned that prior to our work [5], there were no data in the literature on the synthesis of fluorine-containing bispyrazoles in which the heterocyclic fragments are bound by a sulfur atom or a sulfonyl group. The synthesis of the first representatives of fluorine-free bis(pyrazolyl)sulfides and sulfones was reported early [6,7].

The development of the methods for the synthesis of bispyrazole derivatives may be interesting due to the possibility of their use as ligands for the preparation of organometallic catalysts as known from the examples of methylene bispyrazoles [8] or new biologically active compounds [9].

\section{Experimental}

${ }^{1} \mathrm{H}$ NMR spectra were registered using a Bruker Avance-400 (400 MHz) spectrometer (internal standard TMS). ${ }^{13} \mathrm{C}$ NMR spectra were registered using a Bruker Avance-500 spectrometer (125.7 MHz), and chemical shifts are shown relatively to the signals of the solvent $\mathrm{CDCl}_{3}(\delta \mathrm{C} 77.16 \mathrm{ppm}), \mathrm{CD}_{3} \mathrm{CN}$ $(\delta 1.32 \mathrm{ppm})$. Carbon nuclei signals were attributed by APT method. ${ }^{19} \mathrm{~F}$ NMR spectra were recorded by means of a Bruker Avance-400 spectrometer (376.5 MHz), internal standard $\mathrm{C}_{6} \mathrm{~F}_{6}(\delta \mathrm{F}-162.9 \mathrm{ppm})$. Melting temperatures were determined on a Boetius apparatus. Elemental analysis was performed at the analytical laboratory of the Institute of Organic Chemistry NAS of Ukraine by express-gravimetry method $(\mathrm{C}, \mathrm{H})$, burning by Sheniger $(\mathrm{S})$. Silica gel Merck 60 was used for the column chromatography. Macherey-Nagel, and Polygram $\otimes$ Sil G/UV254 plates were used for the thin-layer chromatography. HPLC/MS analyses were carried out using a system consisting of an Agilent 1100 Series high performance liquid chromatography equipped with a diodematrix and an Agilent LC/MSD SL mass selective detector (ionization method: chemical ionization under atmospheric pressure). GC/MS data were obtained on the Hewlett-Packard 5890/5972 apparatus (GC/MS) at $70 \mathrm{eV}$ in the electron impact mode. All solvents were dried and distilled according to standard routines. Diazomethane was obtained from nitrosomethylurea according to the literature method [10] using methyl tert-butyl ether. sulfones

Preparation of bis(polyfluorometoxyalkenyl)-

The syntheses of the compounds were conducted under argon atmosphere. To a stirred solution of polyfluoroalkylsulfone $(4 \mathrm{a}, 2 \mathrm{~g}, 0.007 \mathrm{~mol})$ or $(4 \mathrm{~b}, 2.1 \mathrm{~g}, 0.00425 \mathrm{~mol})$ in $10 \mathrm{ml}$ of anhydrous diethyl ether and methanol (for $4 \mathrm{a}, 0.44 \mathrm{~g}$, $0.014 \mathrm{~mol}$ ), (for $4 \mathrm{~b}, 0.27 \mathrm{~g}, 0.0085 \mathrm{~mol}$ ), the solution of triethylamine (for $4 \mathrm{a}, 2.75 \mathrm{~g}, 0.027 \mathrm{~mol}$ ) (for $4 \mathrm{~b}$, $1.72 \mathrm{~g}, 0.0170 \mathrm{~mol}$ in $10 \mathrm{ml}$ of anhydrous diethyl ether was added at room temperature. After completion of the addition (10 $\mathrm{min})$, the mixture was stirred for $2 \mathrm{~h}$. After that time, chlorotrimethylsilane (for $4 \mathrm{a}, 2.95 \mathrm{~g}, 0.027 \mathrm{~mol}$ ) or (for $4 \mathrm{~b}, 0.38 \mathrm{~g}, 0.0346 \mathrm{~mol}$ ) was added. The solution was stirred at room temperature for $1 \mathrm{~h}$. The precipitate of triethylamine hydrochloride was filtered. Filtrate was evaporated under vacuum 10$20 \mathrm{~mm} \mathrm{Hg}$ at $30-35^{\circ} \mathrm{C}$ and purified.

1-((3,3-Difluoro-2-methoxyprop-1-en-1yl)sulfonyl)-3,3-difluoro-2-methoxyprop-1-ene (6 a) (3 isomers). The compound was purified by silica gel column chromatography, eluent $\mathrm{CH}_{2} \mathrm{Cl}_{2}$. Yield: $0.41 \mathrm{~g},(25 \%)$. Dark yellow liquid. Mass spectrum, $\mathrm{m} / \mathrm{z}$, time $\left(\mathrm{I}_{\mathrm{rel}}, \%, \mathrm{~min}\right): 278.0[\mathrm{M}](65), 7.17 ; 278.0$ [M] (27), 7.60;278.0 [M] (8), 8.22.

$3,3,4,4,5,5$ - Hexafluoro- 1 - $((3,3,4,4,5,5$ hexafluoro-2-methoxypent-1-en-1-yl)sulfonyl)-2methoxypent-1-ene $(6 \mathrm{~b})$. The compound was purified by several time extraction of warm hexane

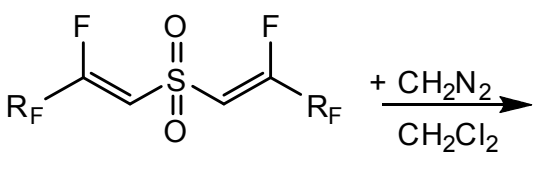

1 (a-c)<smiles>[R7]c1cnn(C)c1S(=O)(=O)c1c([R7])cnn1C</smiles>

2 (a-c)<smiles>[R7]c1cn(C)nc1S(=O)(=O)c1c([R7])cnn1C</smiles>

$3(a-c)$

$$
\left.\mathrm{R}_{\mathrm{F}}=\mathrm{a}\right) \mathrm{H}\left(\mathrm{CF}_{2}\right) \text {; b) } \mathrm{H}\left(\mathrm{CF}_{2}\right)_{3} \text {; c) } \mathrm{H}\left(\mathrm{CF}_{2}\right)_{5} \text {. }
$$

Scheme 1 
from residue. After evaporation of hexane, yellow viscous liquid was formed. Yield $0.8 \mathrm{~g},(40 \%)$.

${ }^{1} \mathrm{H}$ NMR $\left(\mathrm{CDCl}_{3}\right), \delta, \operatorname{ppm}(\mathrm{J}, \mathrm{Hz}): 4.13(\mathrm{~s}$, $\left.6 \mathrm{H}, 2 \mathrm{OCH}_{3}\right), 6.00\left(\mathrm{tt}, 2 \mathrm{H}, 2 \mathrm{CHF}_{2}, \mathrm{~J} 52.0 \mathrm{~Hz}, \mathrm{~J} 4.8\right.$ $\mathrm{Hz}), 6.51(\mathrm{~s}, 2 \mathrm{H}, 2 \mathrm{CH}) \cdot{ }^{13} \mathrm{C} \mathrm{NMR}\left(\mathrm{CDCl}_{3}\right), \delta, \mathrm{ppm}$ $(\mathrm{J}, \mathrm{Hz}): 64.6\left(\mathrm{~s}, 2 \mathrm{OCH}_{3}\right), 108.0\left(\mathrm{tt}, 2 \mathrm{CHF}_{2}, \mathrm{~J} 254.0\right.$ $\mathrm{Hz}, \mathrm{J} 32.1 \mathrm{~Hz}), 111.9\left(\mathrm{tt}, 4 \mathrm{CF}_{2}, \mathrm{~J} 261.7 \mathrm{~Hz}, \mathrm{~J} 31.8\right.$ $\mathrm{Hz}), 119.7$ (t, 2CH, J $4.9 \mathrm{~Hz}), 154.3$ (t, 2C, J 25.4 $\mathrm{Hz}) .{ }^{19} \mathrm{~F}$ NMR $\left(\mathrm{CDCl}_{3}\right), \delta, \mathrm{ppm}(\mathrm{J}, \mathrm{Hz}):-137.91$ (d.m, 4F, $2 \mathrm{CHF}_{2}$, J $\left.51.9 \mathrm{~Hz}\right),-130.89$ (m, 4F, $\left.2 \mathrm{CF}_{2}\right),-117.39\left(\mathrm{t}, 4 \mathrm{~F}, 2 \mathrm{CF}_{2}, \mathrm{~J} 7.9 \mathrm{~Hz}\right)$. Mass spectrum, $\mathrm{m} / \mathrm{z}$, time $\left(\mathrm{I}_{\text {rel }}, \%, \mathrm{~min}\right): 478.2[\mathrm{M}](100)$, 1.10. Found, \%: C 30.10; H 2.04; S 6.61; $\mathrm{C}_{12} \mathrm{H}_{10} \mathrm{~F}_{12} \mathrm{O}_{4} \mathrm{~S}$. Calculated, \%: C 30.14; H 2.11; S 6.70 .

Preparation of bis3-((3,3-difluoro-2,2dimethoxypropyl)sulfonyl)-1,1-difluoro-2,2dimethoxypropane (7a)

To a suspension of lithium hydroxide monohydrate $(1.32 \mathrm{~g}, 0.0315 \mathrm{~mol})$ in methanol $(5 \mathrm{ml})$, a solution of 1,1,2,2-tetrafluoro-3-( $(2,2,3,3-$ tetrafluoropropyl)sulfonyl)propane (4 a) ( $2 \mathrm{~g}, 0.07 \mathrm{~mol})$ in methanol $(3 \mathrm{ml})$ was added. The reaction mixture was stirred at room temperature for 4 hours and diluted with anhydrous diethyl ether $(30 \mathrm{ml})$. The precipitated lithium salts were filtered off, the filtrate was washed with water $(3 \times 5 \mathrm{ml})$. The organic layer was separated and dried over sodium sulfate. The sodium sulfate precipitate was filtered off and filtrate was evaporated in a vacuum of $10-20 \mathrm{~mm} \mathrm{Hg}$. The product obtained in the residue does not require additional purification.

Yield $1.21 \mathrm{~g},(50 \%)$, yellow powder, m.p. 79$80^{\circ} \mathrm{C} .{ }^{1} \mathrm{H}$ NMR $\left(\mathrm{CDCl}_{3}\right), \delta$, ppm $(\mathrm{J}, \mathrm{Hz}): 3.44(\mathrm{~s}$, $\left.12 \mathrm{H}, 4 \mathrm{OCH}_{3}\right), 3.70\left(\mathrm{~s}, 4 \mathrm{H}, 2 \mathrm{CH}_{2}\right), 6.14(\mathrm{t}, 2 \mathrm{H}$, $\left.2 \mathrm{CHF}_{2}, \mathrm{~J} 54.4 \mathrm{~Hz}\right) .{ }^{13} \mathrm{C} \mathrm{NMR}\left(\mathrm{CDCl}_{3}\right), \delta$, ppm $(\mathrm{J}$, $\mathrm{Hz}): 50.55\left(\mathrm{~s}, 4 \mathrm{OCH}_{3}\right), 50.7\left(\mathrm{~s}, 2 \mathrm{CH}_{2}\right), 97.1(\mathrm{t}, 2 \mathrm{C}$, J $22.3 \mathrm{~Hz}), 113.2\left(\mathrm{t}, 2 \mathrm{CHF}_{2}, \mathrm{~J} 252.9 \mathrm{~Hz}\right) .{ }^{19} \mathrm{~F} \mathrm{NMR}$ $\left(\mathrm{CDCl}_{3}\right), \delta, \operatorname{ppm}(\mathrm{J}, \mathrm{Hz}):-133.11\left(\mathrm{~d}, 4 \mathrm{~F}, 2 \mathrm{CHF}_{2}, \mathrm{~J}\right.$ $54.1 \mathrm{~Hz}$ ).

Mass spectrum, $\mathrm{m} / \mathrm{z}$, time $\left(\mathrm{I}_{\mathrm{rel}}, \%, \mathrm{~min}\right): 360.2$ $\left[\mathrm{M}+\mathrm{H}_{2} \mathrm{O}\right](100), 0.94$.

Found, \%: C 34.98; H 5.19; S 9.30; $\mathrm{C}_{10} \mathrm{H}_{18} \mathrm{~F}_{4} \mathrm{O}_{6} \mathrm{~S}$. Calculated, \%: C 35.09; H 5.30; $\mathrm{S} 9.37$. Synthesis of dipyrazolyl sulfones $(2 a, 8)$

A solution of bis(polyfluorometoxyalkenyl)sulfones $(6 \mathrm{a}, \mathrm{b})$ or 1,4-oxathiine-4,4-dioxide $(5 \mathrm{~b})$ $(0.0012 \mathrm{~mol})$ in $\mathrm{CH}_{2} \mathrm{Cl}_{2}(8 \mathrm{ml})$ was added dropwise to a cooled $\left(0^{\circ} \mathrm{C}\right) 0.9 \mathrm{M}$ solution of diazomethane in methyl tert-butyl ether $(10 \mathrm{ml})$ at such a rate that does not allow the reaction mixture temperature to exceed $5^{\circ} \mathrm{C}$. The mixture was stirred at $0-5^{\circ} \mathrm{C}$ for $2 \mathrm{~h}$ and at $20^{\circ} \mathrm{C}$ for $12 \mathrm{~h}$. The reaction mixture was filtered, and the filtrate was evaporated under reduced pressure $(10-20 \mathrm{~mm} \mathrm{Hg})$. The residue was purified by silica gel column chromatography.

From (6 a), 5,5'-sulfonylbis[4-(difluoromethyl)1-methyl-1H-pyrazole] (2 a), eluent ethyl acetate/ hexane $7 / 3$. Yield $0.13 \mathrm{~g},(31 \%)$. The spectral data of the obtained compound correspond to the data obtained earlier [5].

From (6 b), 4,4'-sulfonylbis(3-(1,1,2,2,3,3hexafluoropropyl)-1-methyl-1H-pyrazole) (8), eluent $\mathrm{CH}_{2} \mathrm{Cl}_{2}$. Yield $0.15 \mathrm{~g},(25 \%)$, White powder, m.p. $138-140^{\circ} \mathrm{C},\left(\left(\mathrm{CH}_{3}\right)_{2} \mathrm{CO}\right)$.

${ }^{1} \mathrm{H}$ NMR $\left(\mathrm{CD}_{3} \mathrm{CN}\right), \delta, \mathrm{ppm}(\mathrm{J}, \mathrm{Hz}): 3.94$ (s, $\left.6 \mathrm{H}, 2 \mathrm{CH}_{3}\right), 6.59\left(\mathrm{tt}, 2 \mathrm{CHF}_{2}, 2 \mathrm{H}, \mathrm{J} 52.0 \mathrm{~Hz}, \mathrm{~J} 6.0\right.$ $\mathrm{Hz}), 8.25(\mathrm{~s}, 2 \mathrm{H}, \mathrm{CH}) \cdot{ }^{13} \mathrm{C}$ NMR $\left(\mathrm{CD}_{3} \mathrm{CN}\right), \delta, \mathrm{ppm}$ $(\mathrm{J}, \mathrm{Hz}): 40.9$ (s, $\left.2 \mathrm{NCH}_{3}\right), 109.6$ (tt, $2 \mathrm{CHF}_{2}, \mathrm{~J}=251.9$ $\mathrm{Hz}, \mathrm{J}=29.6 \mathrm{~Hz}$,), 113.5 (tt, 4CF, J $252.5 \mathrm{~Hz}, \mathrm{~J} 30.1$ $\mathrm{Hz}), 125.5\left(\mathrm{~s}, 2 \mathrm{CSO}_{2}\right), 138.7\left(\mathrm{t}, 2 \mathrm{CCF}_{2}, \mathrm{~J} 31.9 \mathrm{~Hz}\right)$, $139.1(\mathrm{~d}, \mathrm{CH}=\mathrm{N}, \mathrm{J} 1.26 \mathrm{~Hz}) .{ }^{19} \mathrm{~F}$ NMR $\left(\mathrm{CD}_{3} \mathrm{CN}\right)$, $\delta, \operatorname{ppm}(\mathrm{J}, \mathrm{Hz}):-137.18$ (d.m, 4F, 2CHF J $51.5 \mathrm{~Hz}),-130.38\left(\mathrm{~m}, 4 \mathrm{~F}, 2 \mathrm{CF}_{2}\right),-104.76(\mathrm{~m}$, $\left.4 \mathrm{~F}, 2 \mathrm{CF}_{2}\right)$. Mass spectrum, $\mathrm{m} / \mathrm{z}$, time $\left(\mathrm{I}_{\mathrm{rel}}, \%, \mathrm{~min}\right)$ : $527.2[\mathrm{M}+\mathrm{H}](100), 1.08$. Found, \%: C 31.67; H 1.83; N 10.51; $\mathrm{S} 6.00 . \mathrm{C}_{14} \mathrm{H}_{10} \mathrm{~F}_{12} \mathrm{~N}_{4} \mathrm{O}_{2} \mathrm{~S}$. Calculated, $\%$ : C 31.95; H 1.92; N 10.65; S 6.09.

5,5'-Sulfonylbis[4-(difluoromethyl)-1-methyl-1Hpyrazole] complex with silver nitrate (15)

5,5'-Sulfonylbis[4-(difluoromethyl)-1-methyl1H-pyrazole] (2 a) $(0.1 \mathrm{~g}, 0.3 \mathrm{mmol})$ was added to a solution of silver nitrate $(0.052 \mathrm{~g}, 0.3 \mathrm{mmol})$ in tetrahydrofuran $(6 \mathrm{ml})$. The resulting solution was stirred for $12 \mathrm{~h}$ at room temperature. The solvent was evaporated in vacuum of $10-20 \mathrm{~mm} \mathrm{Hg}$ at $20^{\circ} \mathrm{C}$ and the residue was crystallized from the mixture of ethyl acetate-acetonitrile (1:1). Yield (40\%), colorless crystals. ${ }^{1} \mathrm{H}$ NMR (DMSO-d 6 ), $\delta$, ppm (J, Hz): 3.91 $\left(\mathrm{s}, 6 \mathrm{H}, 2 \mathrm{CH}_{3}\right), 7.33\left(\mathrm{~d}, 2 \mathrm{H}, 2 \mathrm{CHF}_{2}, \mathrm{~J} 54.4 \mathrm{~Hz}\right)$, $8.13(\mathrm{~s}, 2 \mathrm{H},-\mathrm{CH}=) .{ }^{19} \mathrm{~F}$ NMR $\left(\mathrm{DMSO}_{-} \mathrm{d}_{6}\right), \delta, \mathrm{ppm}$ $(\mathrm{J}, \mathrm{Hz}): 109.06\left(\mathrm{~d}, 4 \mathrm{~F}, 2 \mathrm{CHF}_{2}\right.$, J $\left.54.0 \mathrm{~Hz}\right)$. Found, $\%$ : C 24.25; $\mathrm{H}$ 2.98; N 14.10; $\mathrm{S}$ 6.59. $\mathrm{C}_{10} \mathrm{H}_{10} \mathrm{AgF}_{4} \mathrm{~N}_{5} \mathrm{O}_{5} \mathrm{~S}$. Calculated, \%: C 24.21; H 2.03; $\mathrm{N} 14.12 ; \mathrm{S} 6.46$.

\section{$X$-ray structure determination of (8)}

Crystal data for $(8) \mathrm{C}_{14} \mathrm{H}_{10} \mathrm{~F}_{12} \mathrm{~N}_{4} \mathrm{O}_{2} \mathrm{~S}, \mathrm{M}=526.3$, triclinic, space group $\mathrm{P}-1, \mathrm{a}=9.3559(13)$, $b=10.3227(15), c=11.2731(16) \AA, \alpha=115.071(8)$, $\beta=103.913(9), \gamma=90.949(9)^{0}, V=948.5(2) \AA^{3}, Z=2$, $\mathrm{d}_{\mathrm{c}}=1.843 \mathrm{~g} \cdot \mathrm{cm}^{-3}, \mu=0.308 \mathrm{~mm}^{-1}, \mathrm{~F}(000)=524$, crystal size ca. $0.21 \times 0.40 \times 0.45 \mathrm{~mm}$. All crystallographic measurements were performed at $223 \mathrm{~K}$ on a Bruker Smart Apex II diffractometer operating in the $\omega$ scans mode. The intensity data were collected within the range of $2.1 \leq \theta \leq 25.8^{0}$ using Mo- $_{\alpha}$ radiation $(\lambda=0.71078 \AA)$. The intensities of 12826 reflections were collected (3625 unique reflections, 
$\mathrm{R}_{\text {merg }}=0.0676$ ). The structure were solved by direct methods and refined by the full-matrix least-squares technique in the anisotropic approximation for nonhydrogen atoms using the Bruker SHELXTL program package $[11,12]$. All $\mathrm{CH}$ hydrogen atoms were placed at calculated positions and refined as «riding» model. Convergence was obtained at $\mathrm{R} 1=0.0673$ and $w R 2=0.1814$ for 2431 observed reflections with $\mathrm{I} \geq 2 \sigma$ (I), R1 $=0.0989$ and $w R 2=0.2125, \mathrm{GOF}=1.053$ for 3625 independent reflections, 300 parameters restraints, the largest and minimal peaks in the final difference map 0.44 and $-0.53 \mathrm{e} / \AA^{3}$. Full crystallographic details have been deposited at Cambridge Crystallographic Data Centre (CCDC). Any request to the CCDC for these materials should quote the full literature citation and reference number CCDC 2088505.

\section{$X$-ray structure determination of (15)}

Crystal data for (15) $\mathrm{AgC}_{10} \mathrm{H}_{10} \mathrm{~F}_{4} \mathrm{~N}_{5} \mathrm{O}_{5} \mathrm{~S}$, $\mathrm{M}=496.16$, monoclinic, space group $\mathrm{P} 2_{1} / \mathrm{c}$, $\mathrm{a}=9.8102(2), \mathrm{b}=11.6206(3), \mathrm{c}=13.5989(3) \AA$, $\beta=100.2514(13)^{0}, V=1525.53(6) \AA^{3}, Z=4, d_{c}=2.160 \mathrm{~g} \mathrm{~cm}^{-3}$, $\mu=1.542 \mathrm{~mm}^{-1}, \mathrm{~F}(000)=976$, crystal size ca. $0.11 \times 0.32 \times 0.38 \mathrm{~mm}$. All crystallographic measurements were performed at $173 \mathrm{~K}$ on a Bruker SmartApex II diffractometer operating in the $\omega$ scans mode. The intensity data were collected within the range of $2.11 \leq \theta \leq 26.40^{\circ}$ using $M o-K_{\alpha}$ radiation $(\lambda=0.71078 \AA)$. The intensities of 15235 reflections were collected (3121 unique reflections, $\left.\mathrm{R}_{\text {merg }}=0.0259\right)$. The structures were solved by direct methods and refined by the full-matrix least-squares technique in the anisotropic approximation for nonhydrogen atoms using the Bruker SHELXTL program package $[11,12]$. All $\mathrm{CH}$ hydrogen atoms were placed at calculated positions and refined as «riding» model. Convergence was obtained at $\mathrm{R} 1=0.0356$ and $\mathrm{wR} 2=0.0973$ for 2779 observed reflections with $\mathrm{I} \geq 2 \sigma(\mathrm{I}), \mathrm{R} 1=0.0402$ and $\mathrm{wR} 2=0.1013, \mathrm{GOF}=1.109$ for 3121 independent reflections, 255 parameters $/ 4$ restraints, the largest and minimal peaks in the final difference map 0.99 and $-0.79 \mathrm{e} / \AA^{3}$. Full crystallographic details have been deposited at Cambridge Crystallographic Data Centre (CCDC). Any request to the CCDC for these materials should quote the full literature citation and reference number CCDC 2088506.

\section{Results and discussion}

The compounds $2(\mathrm{a}-\mathrm{c})$ and $3(\mathrm{a}-\mathrm{c})$ have been obtained as a result of the attachment of diazomethane at a multiple carbon-carbon bond of vinyl fluoride $1(\mathrm{a}-\mathrm{c})$ resulting from the dehydrofluorination of 1,1-dihydropolyfluoroalkyl sulfones $4(\mathrm{a}-\mathrm{c})$ under action of organic bases [13] (Scheme 2). The main preparative problem we confronted in the synthesis of bispyrazoles from vinyl fluorides was extremely high reactivity of these compounds $1(\mathrm{a}-\mathrm{c})$ with respect to nucleophiles.

Thus, the presence of even traces of water in the reaction mixture leads to the formation of hydrolysis products of vinyl fluorides, oxathiines 5 $(a-c)$, which reduces the yield of the target bispyrazoles $2(\mathrm{a}-\mathrm{c})$ and $3(\mathrm{a}-\mathrm{c})$.

In present work, we studied the possibility to use bisvinyl ethers $6(a, b)$ for the synthesis of bis(pyrazolyl)sulfones $2(\mathrm{a}, \mathrm{b})$. These compounds are also formed from bis(1,1-dihydropolyfluoroalkyl)sulfones $4(a, b)$, but being more inert with respect to water.

To synthesize alkoxyvinyl sulfones $6(a, b)$ we studied the reaction of bis-sulfones $4(\mathrm{a}, \mathrm{b})$ with methanol in the presence of bases (Scheme 3).

When triethylamine acts on bis-sulfones 4 (a, b), formation of vinyl fluorides $1(a, b)$ occurs, and their reaction with methanol leads to a mixture of isomeric vinyl esters $6(a, b)$, as evidenced by data of GC-MS mass spectrometry, indicating the formation of three compounds with identical values of the molecular weight corresponding to the molecular weight of vinyl ester.

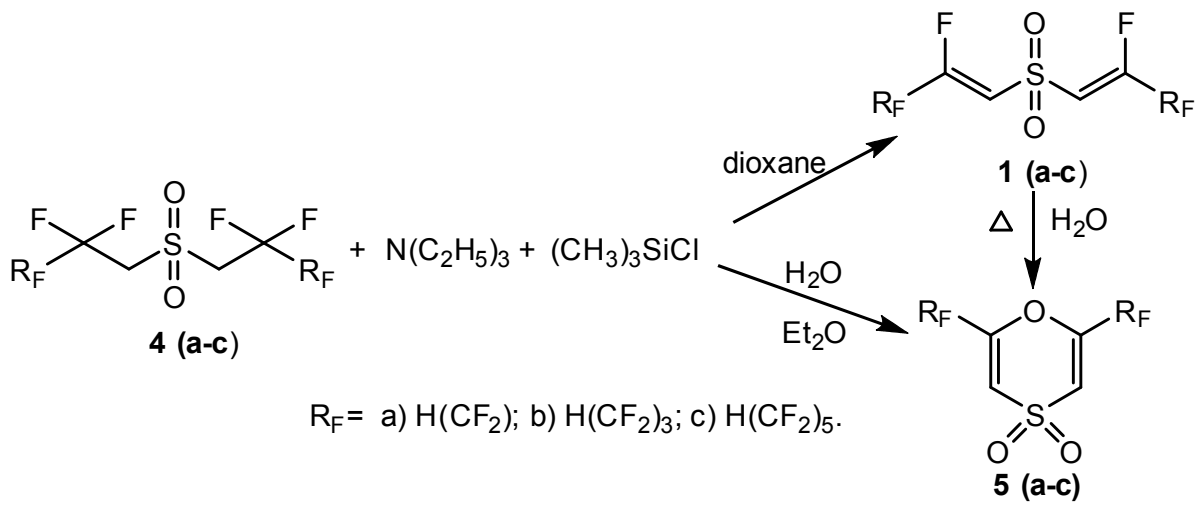

Scheme 2 
<smiles>[R]C(F)(F)CS(=O)(=O)CC([R])(F)F</smiles>

4 a, b

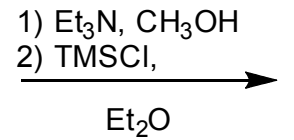

$\mathrm{Et}_{2} \mathrm{O}$<smiles>[R]C(F)=CS(=O)(=O)C=C([R])OC</smiles>

$6 \mathrm{a}, \mathrm{b}$<smiles>CO/C(=C\S(=O)(=O)/C=C(\OC)C(F)(F)C(F)(F)C(F)(F)C(F)F)C(F)(F)C(F)F</smiles>

6<smiles>COC(CS(=O)(=O)CC(OC)(OC)C(F)F)(OC)C(F)F</smiles>

4 a

Scheme 3

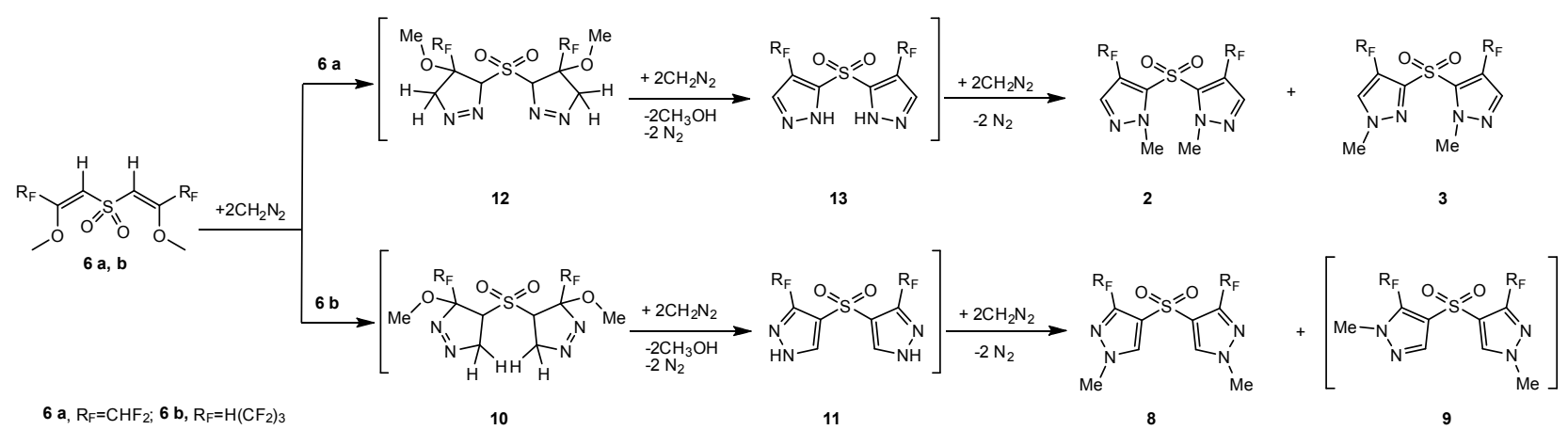

Scheme 4

In case of the compounds with hexafluoropropyl group, the isomer formed in the largest quantity $6 \mathrm{~b}$ was isolated chromatographically. The compound $6 \mathrm{~b}$ has a structure with a trans-position of the OMe and proton.

The molecules of these new types of vinyl sulfones also contain multiple carbon-carbon bonds with sulfonyl and polyfluoroalkyl substituents at unsaturated carbon atoms.

Taking into account the close nature of the substituents at unsaturated carbon atoms (the difference only in the case of fluorine atoms in divinyl sulfones $1(a, b)$ and oxygen in the case of divinyl ethers $6(a, b)$, we hypothesized that $6(a, b)$ compounds can also react with diazomethane to form addition products via $\mathrm{C}=\mathrm{C}$ bonds. We studied the reactions of isomer $6 \mathrm{~b}$ and a mixture of isomers $6 \mathrm{a}$ without separation, with diazomethane.

Indeed, compounds 6 react with diazomethane at room temperature, but the structure of the resulting bispirasolyl sulfones is determined by the influence of the polyfluoroalkyl substituent. In case of divinyl ether 6 a with difluoromethyl substituent, the main reaction product is a bis(pyrazolyl)sulfone 2 a similar to that obtained earlier from divinyl fluoride 1 a (Scheme 4).
In contrast, divinyl sulfone $6 \mathrm{~b}$ with a longer hexafluoropropyl substituent reacts with diazomethane to form a mixture of two isomeric bis(pyrazoles) $8 / 9$, formed in the ratio 1:0.4. The structure of the compounds was deduced from NMR spectroscopy data and the composition was determined from data of chromato-mass spectrometry and elemental analysis. The structure of the isomer 8 formed in larger amounts was confirmed by X-ray structure analysis data (Fig. 1).

It appears that the compounds obtained are isomers of compounds $2(\mathrm{a}-\mathrm{c})$ derived from vinyl fluorides $1(\mathrm{a}-\mathrm{c})$. Apparently, substitution of fluorine atom for oxygen in vinyl fragment has a decisive influence on regioselectivity of diazomethane addition in $\mathrm{C}=\mathrm{C}$ bond. A presumed reaction scheme consists in the initial formation of the adduct 10, subsequent cleavage of the bond $\mathrm{C}-\mathrm{O}$ in this adduct and elimination of methanol leads to the formation of a compound 11, which is further methylated. Its subsequent methylation of nitrogen atoms with diazomethane leads to the formation of isomers 8 .

Similarly, the reaction of oxathiine 5 with diazomethane forms a mixture of bispyrazoles with the formation of compound 8 as a main product (Scheme 5). 


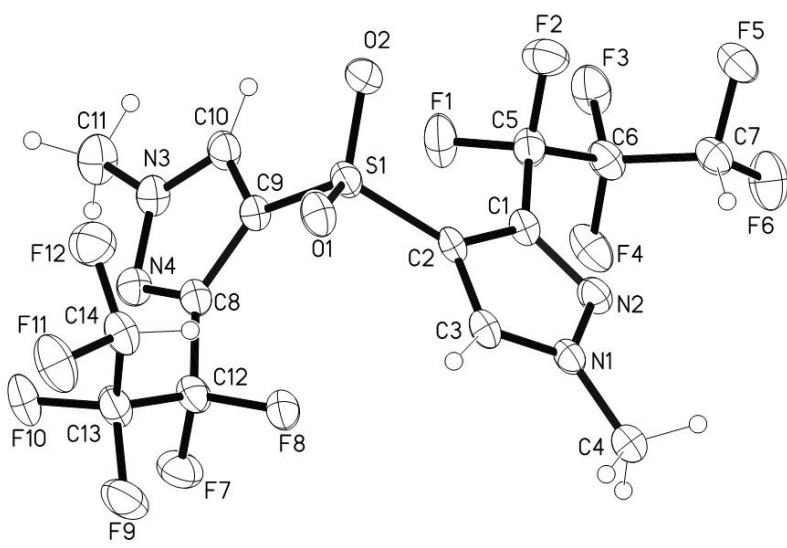

Fig. 1. Molecular structure and selected bond lengths and angles for (8) $\mathrm{C} 1 \mathrm{C} 2$ 1.419(5), C2C3 1.375(5), C3N1 1.336(5),

N1N2 1.349(4), C1N2 1.327(5), C8C9 1.411(5), C9C10

1.368(6), C10N3 1.330(5), N3N4 1.353(5), C8N4 1.326(5) ^;

C3C2C1 104.3(3), N1C3C2 107.4(3), C3N1N2 112.3(3),

C1N2N1 105.3(3), N2C1C2 110.7(3), C10C9C8 104.3(3),

N3C10C9 107.7(4), C10N3N4 112.1(3), C8N4N3 104.8(3),

N4C8C9 111.0(4), C2S1C9 106.74(18) ${ }^{0}$

It appears that the compounds obtained are isomers of compounds 2 (a-c) derived from vinyl fluorides $1(\mathrm{a}-\mathrm{c})$. Apparently, substitution of fluorine atom for oxygen in vinyl fragment has a decisive influence on regioselectivity of diazomethane addition in $\mathrm{C}=\mathrm{C}$ bond. A presumed reaction scheme consists in the initial formation of the adduct 10 , subsequent cleavage of the bond $\mathrm{C}-\mathrm{O}$ in this adduct and elimination of methanol leads to the formation of a compound 11, which is further methylated. Its subsequent methylation of nitrogen atoms with diazomethane leads to the formation of isomers 8 .

Similarly, the reaction of oxathiine 5 with diazomethane forms a mixture of bispyrazoles with the formation of compound 8 as a main product (Scheme 5).

Apparently, in this case, the addition of a diazomethane molecule also occurs with the subsequent cleavage of the bond $\mathrm{C}-\mathrm{O}$. Investigation of the reactions of obtained bis(pyrazoly)sulfones with silver nitrate showed that a stable complex was formed only in case of the compound 2 a (Scheme 6).

\section{$X$-ray structure determination}

In the frame of the extended bipyrazolyl ligand $\mathrm{Pz}-\mathrm{SO}_{2}-\mathrm{Pz}$ (were $\mathrm{Pz}=3,5$ difluorometyl methyl pirazole), two planar pyrazole fragments separated by $\mathrm{SO} 2$ spacer acts as an angular linker which can be easily tuned by the conformational flexibility of the organic linker. In present structure, this angular ligand adopts conformation with dihedral angle between $\mathrm{Pz}$ rings of $85.0^{\circ}$. The structure features of the complex (15) is an infinite $\left(\mathrm{Ag}-\mathrm{Pz}-\mathrm{SO}_{2}-\mathrm{Pz}-\right)_{\mathrm{n}}$ helical chains with bridging dipyrazole ligands between metal centers (Fig. 2).

The coordination environment for $\mathrm{Ag}$ ions in crystal compound (15) are shown in Fig. 3. Silver is coordinated by two $\mathrm{N}$ atoms of neighboring ligands $(\mathrm{Ag}-\mathrm{N}$ distances are in the range of 2.232-2.251(3) $\AA$ ) and tree oxygen atoms (all $\mathrm{Ag}-\mathrm{O}$ distances are within the range of 2.567-2.678(3) $\AA$ ), two of which belong to the bidentate coordinated $\mathrm{NO}_{3}{ }^{-}$anion and the third belongs to to the bridging oxygen atom of the neighboring nitrate anion $(1-\mathrm{x},-\mathrm{y},-\mathrm{z})$.

Thus, nitrate anions also connect two neighboring $\mathrm{Ag}$ atoms as well as two helical chains (Fig. 4) together. Also, weak Ag·F $(x,-0.5+y,-0.5+z)$ interaction was found in the crystal within the distance of 2.930(3) $\AA$, which is significantly shorter

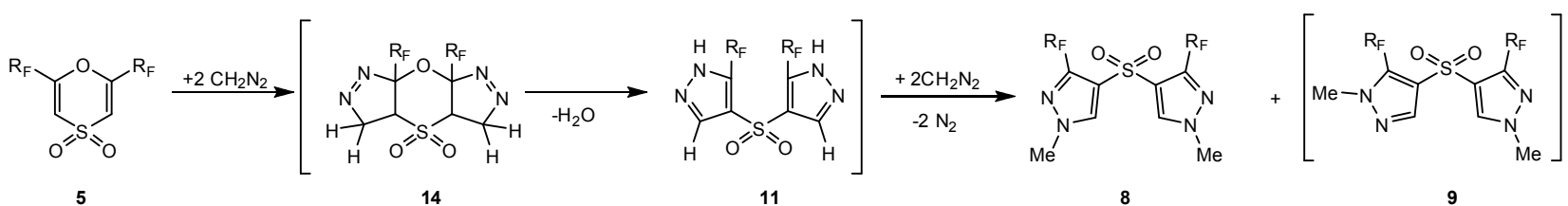

Scheme 5<smiles>Cn1ncc(C(F)F)c1S(=O)(=O)c1c(C(F)F)cnn1C</smiles>

2 a

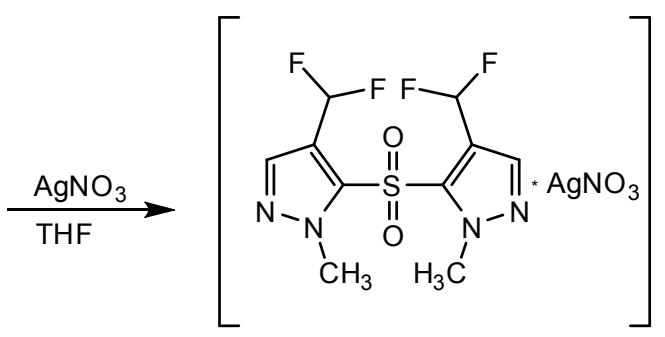

15

Scheme 6 


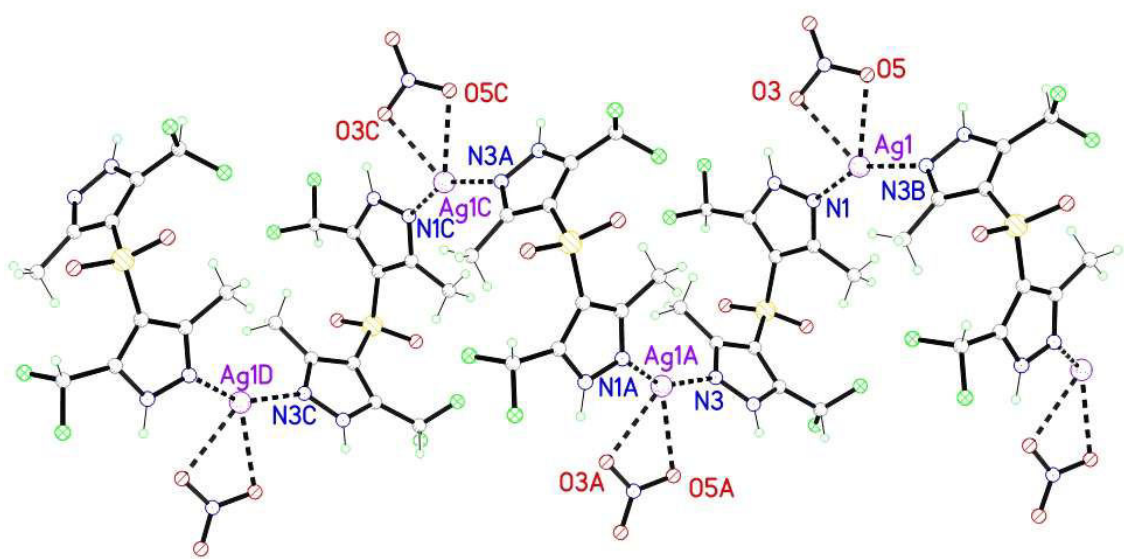

Fig. 2. An infinite helical chains in the structure of complex (15)

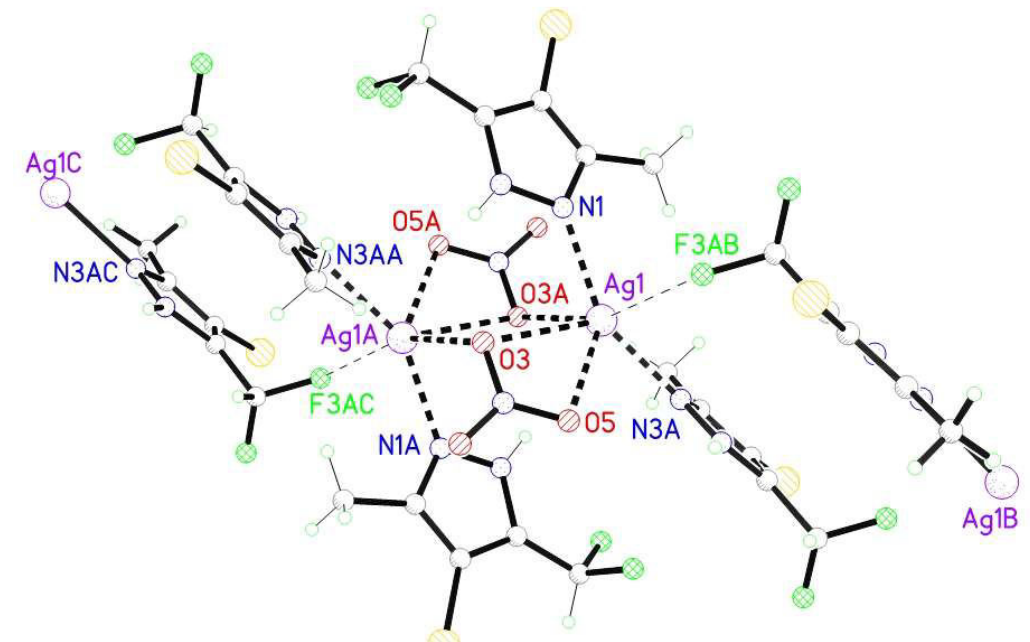

Fig. 3. The coordination environment of Ag atom in complex (15)

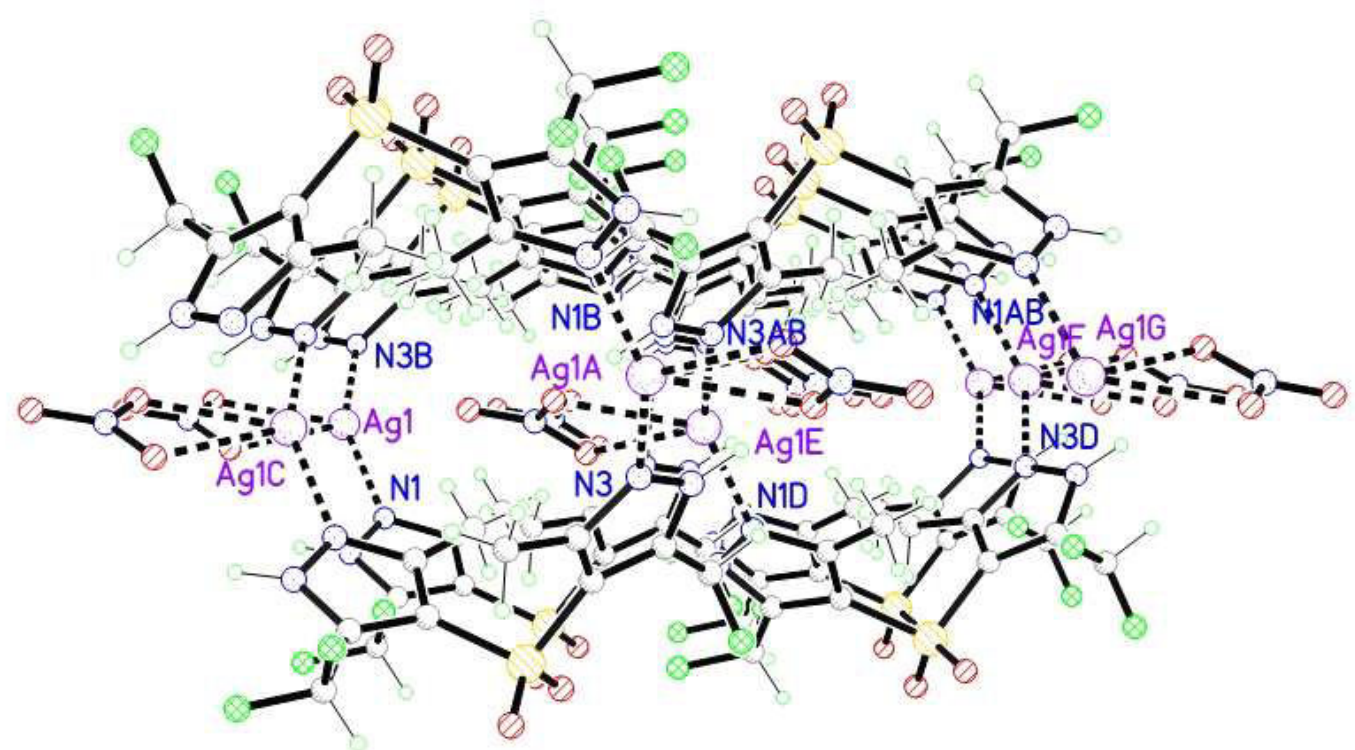

Fig. 4. Crystal packing motif of structure in complex (15) with two neighboring chains directed along crystallographic $0 \mathrm{~b}$ direction (the $\mathrm{Ag}-\mathrm{O}$ bonds between neighboring chains are not shown for clarity) 
the sum of Van der Waals radii for $\mathrm{Ag}$ and $\mathrm{F}$ atoms (3.6 Å) [12]. Taking into account this interaction, the coordination number of silver in complex (15) reaches 6 .

The shortest $\mathrm{Ag}-\mathrm{Ag}(1-\mathrm{x},-\mathrm{y},-\mathrm{z})$ separation in crystal is $3.893 \AA$. Each nitrate anions are located outside the chain (Fig. 4), but inside cavities of the neighboring helical chain, so these cavities completely filled by nitrate anions.

\section{Conclusions}

The reactions of bis (polyfluoroalkenyl)sulfones, bis (polyfluoromethoxyalkenyl)sulfones with diazomethane are convenient methods for the synthesis of previously unknown regioisomers of bis (N-methylpyrazolyl)sulfones. One of the obtained isomers, 5,5'-sulfonylbis[4- (difluoromethyl)-1methyl-1H-pyrazole], forms a coordination polymeric metal complex with silver nitrate. This allows supposing wide possibilities for using such bis (N-methylpyrazolyl)sulfones to obtain metal complex compounds in order to study their subsequent use in medicinal chemistry or as catalysts in organic synthesis.

\section{REFERENCES}

1. Li X., Yu Y., Tu $Z$. Pyrazole scaffold synthesis, functionalization, and applications in Alzheimer's disease and Parkinson's disease treatment (2011-2020) // Molecules. - 2021. - Vol.26. - No. 5. - Art. No. 1202.

2. The therapeutic voyage of pyrazole and its analogs: a review / Khan M.F., Alam M.M., Verma G., Akhtar W., Akhter M., Shaquiquzzaman M. // Eur. J. Med. Chem. - 2016. - Vol.120. - P.170-201.

3. Synthesis and pharmacological activities of pyrazole derivatives: a review / Karrouchi K., Radi S., Ramli Y., Taouflk J., Mabkhot Y.N., Al-Aizari F.A., et al. // Molecules. - 2018. Vol.23. - No. 1. - Art. No. 134.

4. Mykhailiuk P.K. Fluorinated pyrazoles: from synthesis to applications // Chem. Rev. - 2021. - Vol.121. - No. 3. P.1670-1715.

5. Synthesis of fluorinated dipyrazolyl sulfones from bis(2fluoro-2-polyfluoroalkylalkenyl) sulfones and diazomethane / Borodkin Ya.S., Rusanov E.B., Khizhan A.I., Shermolovich Yu.G. // Chem. Heterocycl. Compd. - 2019. - Vol.55. - No. 11. P.1065-1069.

6. Finar I.L., Lord G.H. The preparation of some pyrazole derivatives // J. Chem. Soc. - 1959. - P.1819-1823.

7. Grandberg I.I. Reaktsii pirazolov s galoidnymi soedineniyami sery // Zh. Obsch. Khim. - 1961. - Vol.31. P.548-554.

8. Novel silver(I) pyrazole-based coordination polymers: synthetic and structural studies / Beheshti A., Zafarian H.R.,
Khorramdin R., Monavvar M.F., Abrahams C.T. // Polyhedron. - 2012. - Vol.48. - No. 1. - P.245-252.

9. New antibacterial silver(I) coordination polymers based on a flexible ditopic pyrazolyl-type ligand / Tabacaru A., Pettinari C., Busila M., Dinica R.M. // Polymers. - 2019. - Vol.11. - Art. No. 1686.

10. Arndt F. Diazomethane // Org. Syntheses Coll. - 1943. - Vol.2. - P.165-166.

11. Sheldrick $G$. A short history of SHELX // Acta Crystallogr. Sect. A. - 2008. - Vol.64. - P.112-122.

12. Batsanov S.S. Van der Waals radii of elements // Inorg. Mater. - 2001. - Vol.37. - P.871-885.

13. Synthesis and chemical properties of di(2-fluoro-2polyfluoroalkyl- alkenyl)sulfides and 2,6-bis(polyfluoroalkyl)-1,4oxathiine 4,4-dioxides / Borodkin Ya., Rusanov E., Marchenko A., Koidan Yu., Shermolovich Yu. // J. Sulphur Chem. - 2019. Vol.40. - No. 4. - P.416-425.

Received 05.05.2021

\section{ІЗОМЕРНІ БІС(ПІРАЗОЛІЛ)СУЛЬФОНИ ОДЕРЖАНІ 3 БІС(1,1-ДИГІДРОПОЛІФЛУОРОРАЛКІЛ)СУЛЬФОНІВ. НОВІ ТИПИ ЛІГАНДІВ МЕТАЛОПОЛІМЕРНИХ КОМПЛЕКСІВ 3 КАТІОНОМ СРІБЛА}

\section{Я.С. Бородкін, Е.Б. Русанов, Ю.Г. Шермолович}

Робота присвячена методам синтезу біс(поліфлуороалкеніл)сульфонів і біс(поліфлуорометоксиалкеніл)сульфонів, а також вивченню їх реакцій з діазометаном, що веде до утворення ізомерів $\mathrm{N}$-метильованих біс(піразоліл)сульфонів. Досліджено методи одержання, неописаних в літературі біс(поліфлуорометоксиалкеніл)сульфонів шляхом додавання триетиламіну і триметилхлоросилану в атмосфері аргону до розчину відповідних біс(поліфлуороалкіл)сульфонів і метанолу в диетиловому етері. Було знайдено спосіб одержання невідомого раніше біс(3,3-діфлуоро-2,2-диметоксипропіл)сульфону. Реакція проходить при кімнатній температури в метанолі за присутності моногідрату гідроксиду літію. Виявлено, що при використанні різних метоксипохідних біс(поліфлуоралкеніл)сульфонів в реакції з діазометаном, в залежності від довжини поліфлуоралкільного фрагменту, утворюються різні регіоізомерні біс(поліфлуороалкілпіразоліл)сульфони. Наведені експериментальні дані дозволяють зробити припущення, шо на атаку подвійного зв'язку метоксипохідних біс(поліфлуоралкеніл)сульфонів молекулою діазометану впливає не тільки наявність алкоксильної групи, але й довжина поліфлуроалкільного замісника. Одержані біс(піразоліл)сульфони досліджувались на можливість їх використання в якості лігандів в хімії металокомплексних сполук. Показано, що 5,5'-сульфонілбіс[4-(дифлуорометил)1-метил-1Н-піразол] утворює полімерну металокомплексну сполуку з нітратом срібла. Наведені результати рентгеноструктурних досліджень одержаної координаційної сполуки. Згідно з цими результатами в кристалі отриманої металокомплексної сполуки атом срібла координується з двома атомами азоту піразольних циклів різних молекул, утворюючи супрамолекулярну структуру. Важливе значення, на нашу думку, в подібному розташуванні має нітратна група, що координується з двома атомами срібла. Як результат, в кристалі ми спостерігаємо супрамолекулярну структуру, що має будову спіралі з деяким вільним простором посередині. 
В роботі також надані результати спектрального та рентгеноструктурного аналізу нової регіоізомерної сполуки біс(3гексафлуоропропіл-1-метилпіразоліл)сульфону.

Ключові слова: біс(1,1-дигідрополіфлуороалкіл)сульфони, біс(піразоліл)сульфони, дипіразольні ліганди, координаційні полімери, комплекси срібла, нітрат срібла.

\section{ISOMERIC BIS(PYRAZOLYL)SULFONES BASED ON BIS(1,1-DIHYDROPOLYFLUOROALKYL)SULFONES. A NEW TYPE OF LIGANDS FOR METAL-POLYMER COMPLEXES WITH SILVER CATION}

Ya.S. Borodkin*, E.B. Rusanov, Yu.G. Shermolovich Institute of Organic Chemistry of the NAS of Ukraine, Kyiv, Ukraine

* e-mail: ja.borodkin@gmail.com

The work is devoted to the methods of synthesis of bis(polyfluoroalkenyl)sulfones and bis(polyfluoromethoxyalkenyl)sulfones as well as to the study of their reactions with diazomethane, resulting in the formation of $\mathrm{N}$-methylated bis(pyrazolyl)sulfones isomers. Methods for the preparation of bis(polyfluoromethoxyalkenyl)sulfones not described previously in the literature have been developed by the addition of triethylamine and trimethylchlorosilane to a solution of the respective bis(polyfluoroalkyl)sulfones and methanol in diethyl ether in an argon atmosphere. A new method for the preparation of a previously unknown bis(3,3-difluoro-2,2-dimethoxypropyl)sulfone was suggested. The reaction occurs at room temperature in methanol in the presence of lithium hydroxide monohydrate. It was found that different regioisomeric bis(polyfluoroalkylpyrazolyl)sulfones are formed when using different methoxy derivatives of bis(polyfluoroalkenyl)sulfones in reaction with diazomethane, depending on the length of the polyfluoroalkyl moiety. These experimental data suggest that the attack of the double bond of methoxy-derived bis(polyfluoroalkenyl)sulfones by a molecule of diazomethane is influenced not only by the presence of an alkoxyl group, but also by the length of the polyfluoroalkyl substituent. The obtained bis(pyrazolyl)sulfones were investigated for the possibility of their use as ligands in the chemistry of metal complexes. It was shown that 5,5'-sulfonylbis[4(difluoromethyl)-1-methyl-1H-pyrazole] forms a polymeric metal complex with silver nitrate. The results of X-ray structural analysis of the prepared coordination compound are presented. According to these results, the silver atom coordinates with two nitrogen atoms of pyrazole cycles of different molecules in the crystal of the obtained metal-complex compound, forming a supramolecular structure. In our opinion, an important role in this arrangement is played by the nitrate group that is coordinated with two silver atoms. As a result, we observed a supramolecular structure in the crystal that had a spiral structure with some free space in the middle. The paper also presents the results of spectral and X-ray diffraction analysis of a new regioisomeric compound of bis(3hexafluoropropyl-1-methylpyrazolyl)sulfone.

Keywords: bis(1,1-dihydropolyfluoroalkyl)sulfones; bis(pyrazoly)sulfones; dipyrazole ligands; coordination polymers; silver complex; silver nitrate.

\section{REFERENCES}

1. Li X, Yu Y, Tu Z. Pyrazole scaffold synthesis, functionalization, and applications in Alzheimer's disease and Parkinson's disease treatment (2011-2020). Molecules. 2021; 26(5): 1202. doi: 10.3390/molecules26051202.

2. Khan MF, Alam MM, Verma G, Akhtar W, Akhter M, Shaquiquzzaman M. The therapeutic voyage of pyrazole and its analogs: a review. Eur J Med Chem. 2016; 120: 170-201. doi: 10.1016/j.ejmech.2016.04.077.

3. Karrouchi K, Radi S, Ramli Y, Taouflk J, Mabkhot YN, Al-Aizari FA, et al. Synthesis and pharmacological activities of pyrazole derivatives: a review. Molecules. 2018; 23(1): 134. doi: 10.3390/molecules23010134.

4. Mykhailiuk PK. Fluorinated pyrazoles: from synthesis to applications. Chem Rev. 2021; 121(3): 1670-1715.

doi: 10.1021/acs.chemrev.0c01015.

5. Borodkin YS, Rusanov EB, Khizhan AI, Shermolovich YG. Synthesis of fluorinated dipyrazolyl sulfones from bis(2fluoro-2-polyfluoroalkylalkenyl) sulfones and diazomethane. Chem Heterocycl Compd. 2019; 55: 1065-1069. doi: $10.1007 / \mathrm{s} 10593-019-02578-3$.

6. Finar IL, Lord GH. The preparation of some pyrazole derivatives. J Chem Soc. 1959; 1819-1823. doi: $10.1039 / J R 9590001819$.

7. Grandberg II. Reaktsii pirazolov s galoidnymi soedineniyami sery [Reaction of pyrazoles with haloid compounds of sulfur]. Zh Obsch Khim. 1961; 31: 548-554. (in Russian).

8. Beheshti A, Zafarian HR, Khorramdin R, Monavvar MF, Abrahams CT. Novel silver(I) pyrazole-based coordination polymers: synthetic and structural studies. Polyhedron. 2012; 48: 245-252. doi: 10.1016/j.poly.2012.08.068.

9. Tabacaru A, Pettinari C, Busila M, Dinica RM. New antibacterial silver(I) coordination polymers based on a flexible ditopic pyrazolyl-type ligand. Polymers. 2019; 11(10): 1686. doi: $10.3390 /$ polym11101686.

10. Arndt F. Diazomethane. Org Synth Coll. 1943; 2: 165. doi: 10.15227/orgsyn.015.0003.

11. Sheldrick GM. A short history of SHELX. Acta Crystallogr A. 2008; 64: 112-122. doi: 10.1107/S0108767307043930.

12. Batsanov SS. Van der Waals radii of elements. Inorg Mater. 2001; 37: 871-885. doi: 10.1023/A:1011625728803.

13. Borodkin Ya, Rusanov E, Marchenko A, Koidan Yu, Shermolovich Yu. Synthesis and chemical properties of di(2fluoro-2-polyfluoroalkyl- alkenyl)sulfides and 2,6bis(polyfluoroalkyl)-1,4-oxathiine 4,4-dioxides. J Sulphur Chem. 2019; 40(4): 416-425. doi: 10.1080/17415993.2019.1596269. 